\title{
Optimization of Building Configuration in Vertical Residential Housing towards Outdoor Thermal Comfort: Case Study of Tambora Flats, Jakarta, Indonesia
}

\author{
Khairani Ayu Rizqi1,** and Budi Prayitno \\ ${ }^{1}$ Department of Architecture and Planning Engineering, Faculty of Engineering, Universitas Gadjah Mada, Jl. Grafika No. 2, Yogyakarta \\ 55281, Indonesia \\ ${ }^{2}$ Faculty of Engineering, Universitas Gadjah Mada, Jl. Grafika No. 2, Yogyakarta 55281, Indonesia \\ ${ }^{*}$ Corresponding author: khairaniayu@yahoo.com
}

KEYWORDS

Simulation

Envi-MET

Optimum

Residential

Thermal comfort

SUBMITTED 4 May 2020

REVISED 18 June 2020

ACCEPTED 19 June 2020

\begin{abstract}
Population growth in Indonesia is not offset by the construction of urban facilities and infrastructure and the improvement of urban services. In densely populated urban areas with narrow residential conditions, the demand for shelter is higher, causing an increase in the price of land and housing. One of the efforts in responding to this problem in the Special Capital Region of Jakarta is to build vertical residential or flats. This study aimed to determine the level of outdoor thermal comfort of Tambora flats in Jakarta, which have air temperatures ranging $26-29^{\circ} \mathrm{C}$ and air humidity of $76-92 \%$. Existing flats were simulated with the Envi-MET 3.1 software, with the first stage being to determine the height of the building and material of the building, the street, and then assessing the existing outdoor thermal comfort level by inputting climatic data. Overall, the thermal comfort index values of both existing and planned model building configurations of Tambora flats and its surrounding area were at the standard level for a humid climate. Of our models, model B had the best potential to provide thermal comfort to humans in the area of the flats. In order to implement the proposed model building configuration with optimal outdoor thermal comfort in real buildings, future research should focus on a wider range of aspects, including diversity and density of buildings, and neighborhood type.
\end{abstract}

(c) The Author(s) 2020. This article is distributed under a Creative Commons Attribution-ShareAlike 4.0 International license.

\section{INTRODUCTION}

The development of urban areas has a variety of impacts on the patterns of life of the urban community itself, including the increasing need for residential areas (Wiarni et al. 2018). The absence of a micro-residential spatial layout in terms of architecture, building layout, building density, building size, height of the balance of open land buildings, and buildings in each parcel of land will result in slums and these settlements have adorned the cities of developing countries. The slum settlement in question is a settlement in which physical materials, settlement facilities, and the environment are below the eligibility standard (Putri 2018).

According to Jessica (2017), in overcoming the problem of the emergence of slums in Indonesia's capital city of Jakarta due to difficulties in fulfilling housing needs, the government is building more effective and efficient surfaces for low-income people by establishing vertical housing or flats. The regional spatial plan and detailed spatial plan have been integrated with the construction of vertical housing, which have entered the national agenda. Pitaloka et al. (2018) found that simple rental apartments in Jakarta mostly have a horizontal circulation typology with a linear corridor path configuration from the focal point of vertical attainment.

The density of urban areas that are supported by various activities in the region has the potential to increase its microclimate. This increase in the microclimate of the re- gion, meanwhile, has the effect of reducing the level of user comfort, one of the indicators of which is seen in the existing thermal conditions (Adityo 2016). According to Aihua Mao in Janesonia (2019), thermal comfort is influenced by two factors, namely climatic conditions and human factors. Climatic conditions are affected by air temperature, radiation temperature, wind speed, and humidity levels, while human factors are affected by metabolism, activity level, and type of clothing. Therefore, we need a design that responds to the microclimate conditions of the region as well as development in synergy with the natural environment to reduce excess energy use and preserve the environment. This research was conducted by designing the area of Tambora flats in the city of Jakarta in consideration of various aspects, such as temperature, solar radiation, and wind movement by conducting tests to determine the level of thermal comfort of the design. The aim of the study was to show which of the building configurations can provide a more comfortable microclimate on the hottest hour of a day.

\section{MATERIALS AND METHODS}

\subsection{Building configuration approach}

The microclimate temperature in a city can be increased or decreased with the rate and flow of wind, which can be adjusted according to the shape of the city so that it becomes 
TABLE 1. The recommended morphological form of the city is based on the type of climate (Sugangga et al. 2018).

\begin{tabular}{ll}
\hline Type of climate & Morphological form of the city \\
\hline Hot - humid & - Scattered shape. \\
& - There are no blocked/blocked roads to support \\
the wind flow. & - Mixed from be compact and clustered. \\
Cold - moist & - Provided several open spaces to adapted with \\
& summer conditions. \\
& - Has protected forms gathered for protection from \\
Snow. & - Morphology with compact city (compact form). \\
Cold - dry & $\begin{array}{l}\text { - The shape of the city is dominated by the } \\
\text { formation of compact cities (compact cities) } \\
\text { which are supported by cluster-shaped areas. }\end{array}$ \\
Oceanfront & $\begin{array}{l}\text { - In humid climate: has a city shape that } \\
\text { spreading especially those close to the coastline. }\end{array}$ \\
& $\begin{array}{l}\text { - Compact shape and buffer is given to the area } \\
\text { within the area, the formation becomes more } \\
\text { open when it close to the shore. }\end{array}$ \\
Semi-compact & $\begin{array}{l}\text { A mixture of compact formations combined with } \\
\text { clusters. }\end{array}$
\end{tabular}

thermal in the region that has a relationship with the shape of the city (Sugangga et al. 2018). In Table 1, Sugangga et al. (2018) lists the morphological forms of the city that are recommended to form a local responsive area.

According to Sugangga et al. (2018), there are three topographical aspects topography that can affect thermal conditions, specifically building height, land slope, and wind exposure. In addition to some of the factors that have been mentioned, land cover and vegetation cover are also factors that influence the formation of high and low temperatures in an area. There are several surface configuration factors that can impact thermal conditions in an area, such as the building floor coefficient, the ratio of open space that has an influence on wind movement, atmospheric heat transfer, and solar radiation. In addition, there is the basic building coefficient, the green base coefficient, and the ratio of water availability in the area.

\subsection{Outdoor Thermal comfort approach}

Thermal comfort in the outdoor environment is mainly related to thermophysiology, namely physiology and the heat balance of the human body (Taleghani et al. 2015). This field of study connects building configurations and landscape designs to biometeorology (more focus in pedestrians) and climatology (more focus on the climate, such as air temperature, wind speed, relative humidity, and temperature radiant). Both biometeorology and climatology have important roles in developing thermal comfort indices such as the universal thermal climate index. Based on ASHRAE Standard 55 , thermal comfort is a condition of satisfaction with the surrounding thermal conditions and is assessed by subjective evaluation (Table 2). To measure the perception level of an urban microclimate's quality and take into design consideration, there is outdoor thermal comfort that will be an essential factor which could improve our understanding of sustainable development (Kusumastuty et al. 2018).

\subsection{Research location}

The location of this study was in the area of Tambora flats, West Jakarta, which is composed of densely populated flats. Tambora flats is located in Angke, West Jakarta, built in 1984 in Jalan Angke Jaya. The site consists of four blocks
TABLE 2. Ranges of the thermal indexes Predicted Mean Vote (PMV) and Physiological Equivalent Temperature (PET) based on ASHRAE 55.

\begin{tabular}{ccll}
\hline PMV & PET & Thermal sensation & Level of heat stress \\
\hline-3.5 & 14 & Very cold & Extreme cold stress \\
-2.5 & 18 & Cold & Strong cold stress \\
-1.5 & 22 & Cool & Moderate cold stress \\
-0.5 & 26 & Slightly cool & Slightly cold stress \\
0 & & Neutral & No thermal stress \\
0.5 & 30 & Slightly warm & Slight heat stress \\
1.5 & 34 & Warm & Moderate heat stress \\
2.5 & 38 & Hot & Strong heat stress \\
3.5 & 42 & Very hot & Extreme heat stress \\
\hline
\end{tabular}

with a total of 600 units (land area $=6,812.69 \mathrm{~m}^{2}$ ) and with a rental system. Tambora flats is located opposite the Krendang River, which separates Krendang Village and Jembatan Lima Village. The old Tambora block apartment has two types of dwellings, namely type 18 and type 21 . Buildings around the flats have various functions, including public, residential, and commercial facilities. The limits of the scope of the Tambora flats are the northern border (Jalan Angke Indah VI), eastern border (Jalan Angke Indah), southern border (Kerendang River), and western border (Jalan Angke Jaya XIV).

Based on 2019 climatology data taken by the Meteorology, Climatology, and Geophysical Agency (BMKG) at the Kemayoran Observation Station (Data Online c2015), the air temperatures in the Special Capital Region of Jakarta ranged from $32.4^{\circ} \mathrm{C}$ to $36.6^{\circ} \mathrm{C}$, while the maximum average temperature acquired in the month of October was $29.3^{\circ} \mathrm{C}$. The lowest average temperature occurred in February and the highest average temperature occurred in May, with an average air temperature of $29.4^{\circ} \mathrm{C}$. Temperature changes in 2019 are considered to be not too significant every month, with the data from BMKG showing an increase and decrease in the average air temperature of just $0.3-0.7^{\circ} \mathrm{C}$. The Special Capital Region of Jakarta, in 2019, had an average humidity of $67-82 \%$. The air humidity in the region was not very significant because of the decline and an increase in humidity levels every month. Nonetheless, the highest average humidity level occurred in February. Wind speed throughout 2019 did not show a significant change, where the increase in wind speed was only around $0-0.2 \mathrm{~m} / \mathrm{s}$. In fact, in April there was a decrease in wind speed of up to 0.5 $\mathrm{m} / \mathrm{s}$ compared with January. According to Anindita (2011), a city will be impacted by the temperature carried by the wind and affect the temperature that is present in the city.

TABLE 3. Variables and indicators.

\begin{tabular}{ll}
\hline Variables & Indicators \\
\hline Building Configuration & Land use \\
& Building shape and mass \\
& Building height \\
& Road network \\
& Open space \\
& Air temperature \\
& Wind speed \\
Outdoor Thermal Comfort & Relative humidity \\
& Temperature radiant \\
\hline
\end{tabular}




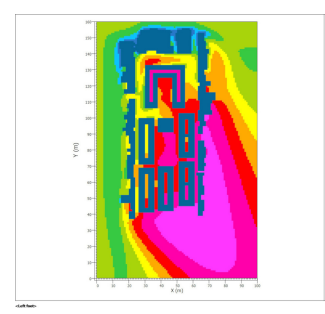

(a) Existing configuration

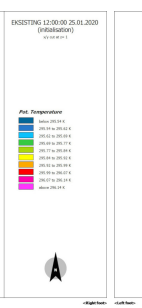

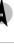

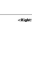

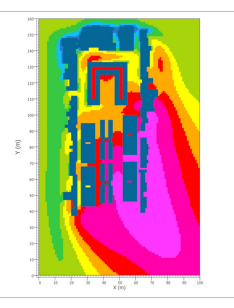

(b) Model A

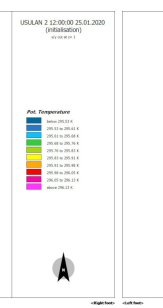

A

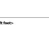

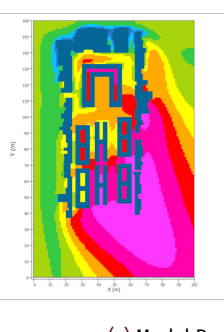

(c) Model B

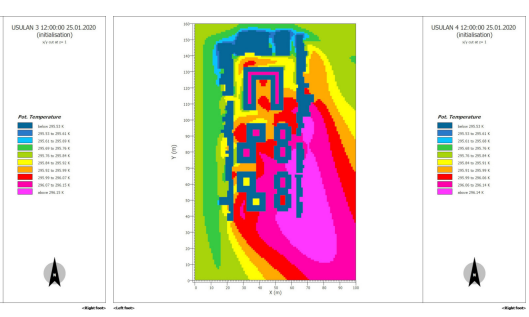

(d) Model C

FIGURE 1. Air temperature distribution at $2 \mathrm{~m}$ height for each model on January 25, 2020, at 12:00 $\mathrm{h}$.

\subsection{Research methods}

This study used field observations to analyze outdoor thermal comfort in the outdoors of vertical housing areas. The tool used was the 2017 Google satellite imagery for detailed land areas, a camera to document the survey results of the observed sites, Autocad 2015, SketchUp 2016, and EnviMET 3.1 for data processing and research report generation. Envi-MET 3.1 was used to predict the modification effects from three different proposal scenarios, and in which a computer simulation was designed to simulate and validate the actual current initial conditions. This program simulated the microclimate data (such as mean radiant temperature, air temperature, relative humidity, and wind speed). The preparation stage before the observation period comprised preparing a basic map for initial data observations. The basic map used must show the environmental boundaries of the observation area and roads, open space, and the top of the building must be clearly visible. Field observations and measuring and documenting the location and variables to be studied included the dimensions of physical elements in the form of the physical height of buildings, building material for flats, distance between flats, road dimensions, vegetation height and activities around flats. In order to find out how the physical condition of the Tambora flats area and the thermal comfort experienced by residents of Tambora flats, a number of variables were set to look at the overall thermal comfort analysis in the observation area. The determination of the research variables and indicators shown in Table 3 were formulated from several literature on thermal comfort in flats, such as Janesonia (2019), who studied thermal comfort in Surabaya, focusing on highrise buildings, midrise buildings, and lowrise buildings; Jessica (2017), who studied a flats environment in Rusunawa Pesakih and Rusunawa Tambora; and Taleghani et al. (2015), who researched five different urban forms in the Netherlands.

This study mapped the existing spatial conditions and thermal comfort that can be achieved by assessing the proposed building configuration and landscaping with three models that correspond to the existing neighborhood in Tambora flats. We simulated diurnal daytime microclimate

TABLE 4. Existing conditions used in the simulations with Envi-MET 3.1 based on BMKG data (Data Online c2015).

\begin{tabular}{ll}
\hline Item & Condition \\
\hline Simulation day & $25 / 01 / 2020$ \\
Simulation period & 01 hour $(12.00-13.00)$ \\
Spatial resolution & 2 m horizontally, 2 m vertically \\
Wind speed $(\mathrm{m} / \mathrm{s})$ & 1 \\
Relative humidity $(\%)$ & 89 \\
Air Temperature $\left({ }^{\circ} \mathrm{C}\right)$ & 27.1 \\
\hline
\end{tabular}

conditions in Envi-MET 3.1 using the parameters determined in the validation process (Table 4), and conducted a micro-level analysis of urban form and landscape design impact at a height of $2 \mathrm{~m}$ air temperature $\left(\mathrm{T}_{2 \mathrm{~m}}\right)$ in the center of the urban forms. We investigated diurnal temperature variations, the spatial temperature distribution at noon (12:00 h) on January 25,2020 , wind speed, and shading in each combined scenario. We also examined the relationship of surface temperatures with surface materials and incoming solar radiation for a high density, building configuration and vegetation landscaping scenario. The next stage was to assess the level of performance of thermal comfort through a comparative analysis on the existing conditions and the proposed mode. The data were entered into a comfort thermal calculator to calculate the Predicted Mean Vote (PMV) based on the sky view factors of the central points. The outdoor thermal comfort of the points will be discussed and compared in this paper.

\section{RESULTS AND DISCUSSION}

For this paper, four urban forms or models, one of which included that of existing conditions, were selected to be assessed in terms of thermal comfort in the temperate climate of the Tambora vertical residential housing, and were simulated for the hottest time in the reference day. The duration of the simulation on the reference point was one hour. In the following discussion, we focus our analysis on the spatial distribution and variation of $2 \mathrm{~m}$ air temperature $\left(\mathrm{T}_{2 \mathrm{~m}}\right)$, wind speed, relative humidity, and temperature radiant, along with the relationship between surface temperatures, short-wave radiation, and surface materials. We particularly focus on the noon microclimate using the example of 12:00 h on January 25, 2020, the time of maximum thermal stress for outdoor thermal.

\subsection{Air temperature $\left({ }^{\circ} \mathrm{C}\right)$}

The air temperature data for the simulations were taken from a Meteorology, Climatology, and Geophysical Agency

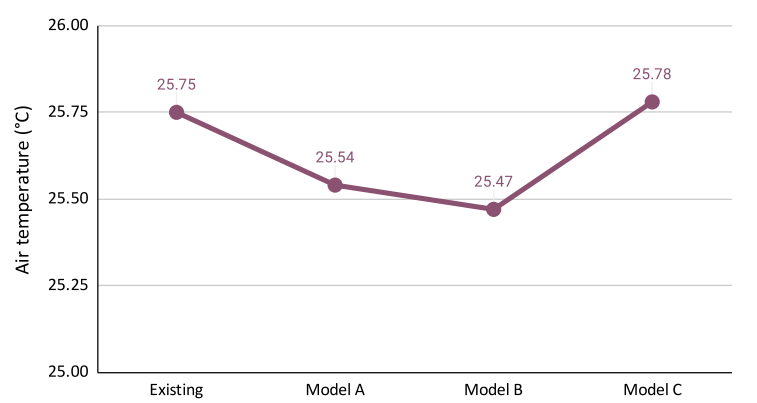

FIGURE 2. Comparison of simulation (Envi-MET) of air temperature results with measurements on January 25, 2020. 


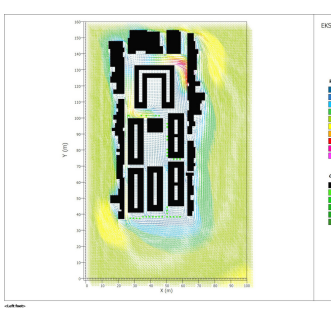

(a) Existing configuration

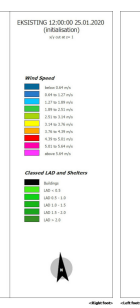

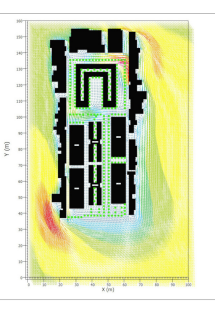

(b) Model A

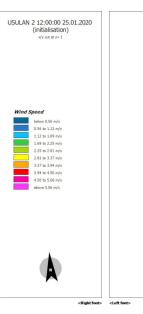

(c) Model B

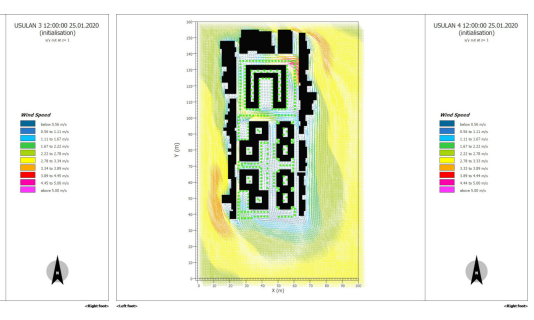

(d) Model C

FIGURE 3. Wind speed distribution at $2 \mathrm{~m}$ height for each model on January 25, 2020, at 12:00 h.

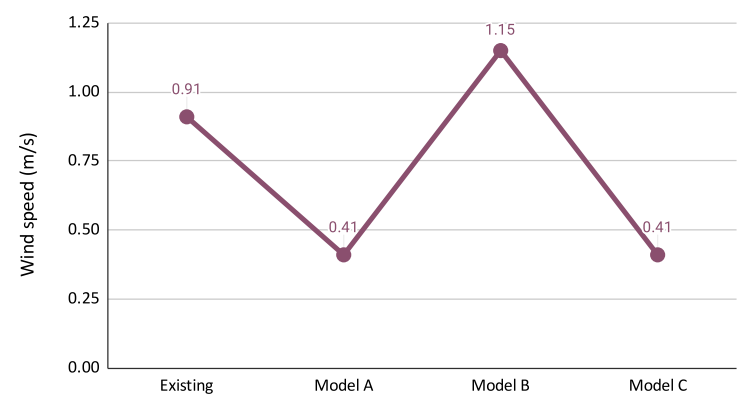

FIGURE 4. Comparison of simulation (Envi-MET) of wind speed results with measurements on January 25, 2020.

(BMKG) Kemayoran station. To determine the accuracy of the simulations (shown in Figure 1), the data from these simulations were compared (Figure 2). The four models including the existing model were simulated for the hottest hour in the reference day. The results show that during the reference day, the air temperature on building configuration model $\mathrm{C}$ had a higher air temperature than the existing conditions, at $25.78^{\circ} \mathrm{C}$, while the lowest air temperature belonged to the building configuration of model $\mathrm{B}\left(25.47^{\circ} \mathrm{C}\right)$.

The air temperature in building configuration model $\mathrm{A}$ was $25.54^{\circ} \mathrm{C}$, making it slightly similar to the existing building configuration's air temperature $\left(25.75^{\circ} \mathrm{C}\right)$. Based on this comparison, it can be seen that the building configuration of model B had the lowest air temperature among the existing configuration (model A) and other building configuration models. The decrease in air temperature level is caused by the shadowing of the configuration of the apartment building. Building configuration model B was adapted by using the principle of spatial integration level and in this principle, Prayitno (2013) observed that a space with high integration value is used as a public space, whereas a space with low integration value is used as a private living space.

\subsection{Wind speed $(\mathrm{m} / \mathrm{s})$}

The wind speed data for the simulations were taken from a BMKG Kemayoran station. As with the air temperature data, to assess the accuracy of the wind speed simulations
(Figure 3), the simulation data were compared (Figure 4). All four models (including the existing model) were simulated for the hottest hour in the reference day, for the duration of one hour. From the graphic above model A, it can be seen that model $\mathrm{C}$ was slightly similar, with a 0.41 $\mathrm{m} / \mathrm{s}$ wind speed and model $\mathrm{B}$ had the highest wind speed among the simulations, with $1.15 \mathrm{~m} / \mathrm{s}$. It was clearly found that the maximum wind speed observed was in model B, with its open space scenario in the center area, while the lowest wind speed was found in models $\mathrm{A}$ and $\mathrm{C}$, with their high density scenarios that can affect wind speeds. Unlike model $\mathrm{B}$, the high density configuration in models A and $\mathrm{C}$ block wind movement, and comparing the wind speed between these three models, a possible reason is that the slab in the building blocks form a series of wind channels which can conduct the wind speed. The building configuration plays a distinguishing role in affecting the distribution of wind speed. The data obtained for Figure 3 were captured at a height of $2 \mathrm{~m}$ at 12:00 h, and in model B, the distributions of the maximum wind speed was found to belong to this building configuration.

\subsection{Relative humidity (\%)}

The relative humidity data for simulations were also taken from a BMKG Kemayoran station, with the simulation results shown in Figure 5 compared for their accuracy, as shown in Figure 6. As aforementioned, the three simulation

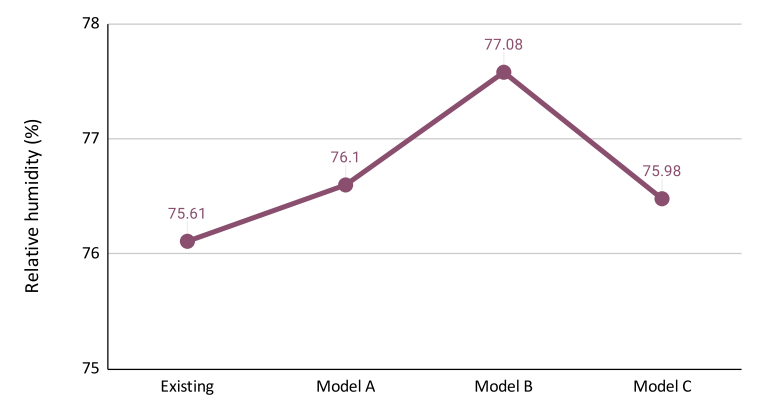

FIGURE 6. Comparison of simulation (Envi-MET) of relative humidity results with measurements on January 25, 2020.

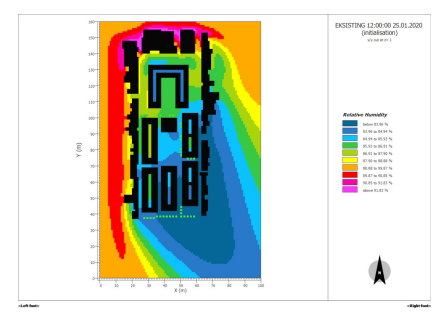

(a) Existing configuration

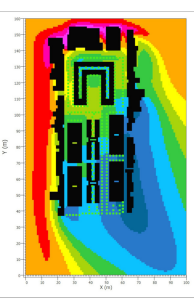

(b) Model A
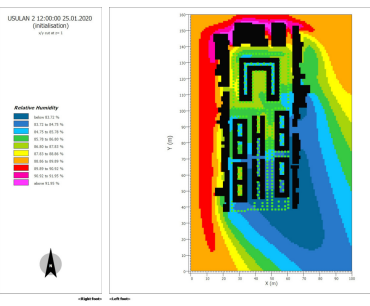

(c) Model B

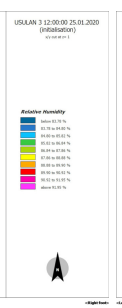

$A$

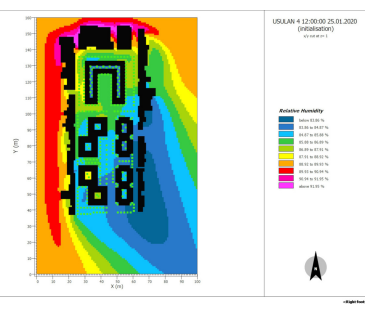

(d) Model C

FIGURE 5. Relative humidity distribution at $2 \mathrm{~m}$ height for each model on January 25, 2020, at 12:00 h. 


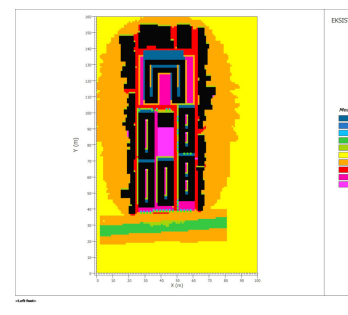

(a) Existing configuration

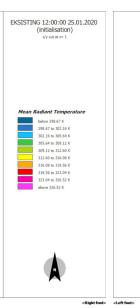

$A$

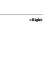

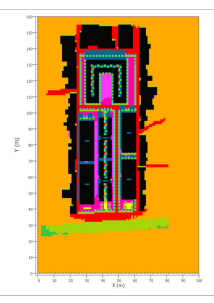

(b) Model A

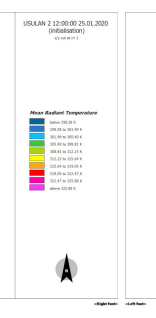

$-\ldots$

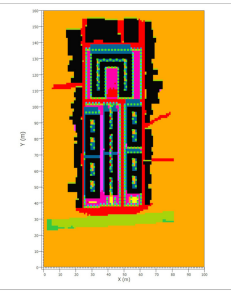

(c) Model B
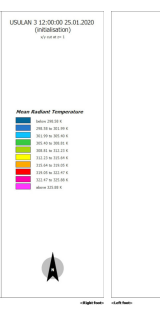

……

(d) Model C

FIGURE 7. Radiant temperature distribution at $2 \mathrm{~m}$ height for each model on January 25, 2020, at 12:00 $\mathrm{h}$.

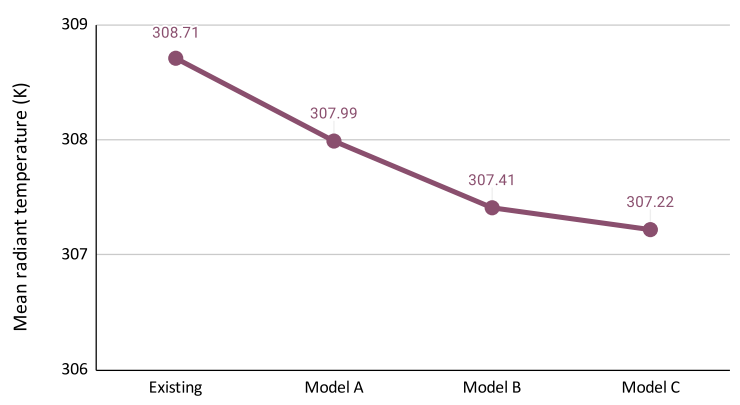

FIGURE 8. Comparison of simulation (Envi-MET) of temperature radiant results with measurements on January 25, 2020.

models and existing model were simulated according to the hottest hour in the reference day. Where relative humidity is concerned, model B had the highest value, with $77.08 \%$, and this result was inversely proportional to model B's simulated air temperature results, with this model having the lowest air temperature $\left(25.47^{\circ} \mathrm{C}\right)$. This shows that in an area that has high air temperatures, at the same time the relative humidity will be low. Model A and model $\mathrm{C}$ both had stable relative humidity levels, even though they still had higher relative humidity than the existing model, $76.1 \%$ and $77.08 \%$, respectively, compared with $75.61 \%$. Both the existing and simulated building configuration models are included in the category of warm comfortable upper limit, based on the SNI 03-6572-2001 standard.

In Figure 1, a hot spot is seen in the space between buildings in model $\mathrm{B}$. This is due to the wind blowing from the open space on the north and south sides and the space between the buildings themselves. The presence of this wind causes the central area of the region to have fewer hot spots than others despite it having high relative humidity.

\subsection{Mean radiant temperature $(\mathrm{K})$}

The mean radiant temperature data for the simulations were obtained from a BMKG Kemayoran station. To assess the accuracy of the simulations (shown in Figure 7), their data were compared, the results of which are shown in Figure 8 . The mean radiant temperature indicates the amount of heat produced by the material that receives heat from sunlight. The amount of heat generated will affect the level of thermal comfort for people, those in the case of this study being residents of Tambora flats. The ability of the material to reflect the sun's heat will largely determine the amount of heat generated by the material in the surrounding environment. The greater the ability to reflect heat, the less heat is released from the absorption of heat by the material to the environment.

Figure 8 shows that there was a tendency for the mean radiant temperature to decrease in the area of Tambora flats, which is influenced by the time of solar circulation in the region. The greater the shadows that can be formed by the building configuration, the cooler the area it covers. Model A, the existing configuration, had the highest mean radiant temperature, with $307.99 \mathrm{~K}$. This temperature is the peak temperature produced due to lack of shade in the flat area of the sun, which causes the temperature of reflections from the roads around the area to be high. Model $\mathrm{C}$ had a decrease in temperature because of the way the area of the Tambora flats is covered by the shadow of the building formed by the angle of falling sunlight.

\subsection{Predicted mean vote (PMV)}

From the results of the analyses of air temperature, wind speed, relative humidity, and mean radiant temperature that occur under existing conditions and the building configurations of models A, B, and C, we can find out the value of the thermal comfort obtained with the Predicted Mean Vote (PMV), which is a measuring tool used to indicate cold to warm sensations that can be felt by humans using a scale of numbers +3 to -3 . In PMV, there are six parameters that will determine the scale of comfort for a person within the environment in which they are present. PMV is a model that is used as a standard for measuring thermal comfort on the ISO 7730 standard of thermal comfort (Anindita 2011). In this condition, the zero (0) value is the most comfortable thermal value felt by humans, meaning that if the PMV value approaches 0 , the thermal conditions in the area will be more comfortable for humans.

As the main factor for the thermal comfort index that was considered in this study, the distribution maps of PMV values for both existing conditions and the building configuration models are presented in Figure 9. At first glance there were no significant changes, even though the building configurations changed considerably. To be more exact, Figure 9 shows that model A had decreased PMV value compared with that of the existing configuration. In model $\mathrm{B}$, the PMV value decreased even further, but it then increased again in model $\mathrm{C}$, above that of the existing configuration and the other models. This indicates that the building configuration of model B can provide the best thermal comfort to humans who are in the area of Tambora flats.

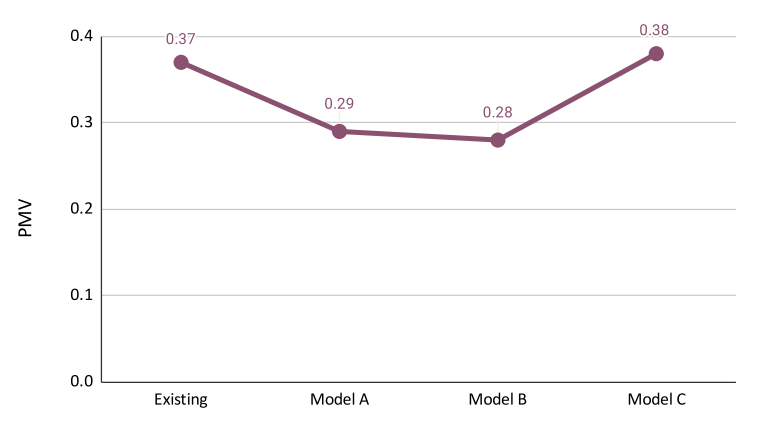

FIGURE 9. PMV results with measurements on January 25, 2020. 


\section{CONCLUSIONS}

Overall, the thermal comfort index values (indicated by their PMV values) of both the existing and investigated building configurations of Tambora flats and the surrounding area were at the standard index for countries with humid climates. Although there are a lot of trees in the area, there were no significant changes. A comparison between the models and their outdoor thermal comfort situations showed that the projected conditions had a lower thermal comfort index than existing conditions. Based on this research and the literature study, it is evident that there are several factors which have an impact on thermal comfort, such as building height, building configuration, and terrace materials. The goal of this study was to find a building configuration that offered an optimal value of outdoor thermal comfort in the Tambora flats area. The most significant conclusion that we can draw from our results is that model B has an optimum PMV value among all the models (0.28). Olgyay (1962) observed that there are certain values that encompass thermal comfort, such as an air temperature between $24^{\circ} \mathrm{C}$ and $28^{\circ} \mathrm{C}$, wind speed between 0.1 and $3.5 \mathrm{~m} / \mathrm{s}$, and relative humidity between $60 \%$ and $90 \%$. The three building configuration models were found to meet Olyglay's thermal comfort standards, although there was no significant difference among them. The proposed approach, based on simulations with EnviMET 3.1 software, is one novelty of this research, for reasons previous discussed. Nonetheless, in order to implement the proposed building configuration models, which had optimal values of outdoor thermal comfort, in real buildings, future research will need to be focused on a wider range of aspects, such as diversity and density of buildings and neighborhood type.

\section{ACKNOWLEDGMENTS}

This article is the result of a thesis research of The Architectural Master Program in the Faculty of Engineering, Universitas Gadjah Mada. Thanks to all of the academic community of Universitas Gadjah Mada.

\section{AUTHORS' CONTRIBUTIONS}

KAR designed, wrote the first draft of the manuscript, and analyzed the data. BP contributed to analyzing the data. Both authors provided works of literature, conducted manuscript proofreading, and approved the final version of the manuscript.

\section{COMPETING INTERESTS}

The authors declare no competing interest.

\section{REFERENCES}

Adityo. 2016. Peningkatan kenyamanan termal koridor jalan melalui desain tata vegetasi berbasis simulasi [Improved thermal comfort of road corridors through design of vegetation based simulation]. Jurnal Arsitektur Komposisi. 10(1):159-168. doi:10.24002/jars.v11i3.1189.

Anindita R. 2011. Kajian kondisi kenyamanan termal pada jalur pejalan kaki di kawasan komersial. Studi kasus:
Jalan Affandi, Yogyakarta [Study of thermal comfort conditions on pedestrian paths in commercial areas. Case study: Affandi Street, Yogyakarta; dissertation]. [Yogyakarta]: Universitas Gadjah Mada.

Data Online: BMKG Database Center. c2015. Jakarta: Meteorology, Climatology, and Geophysical Agency; [accessed 2020 May 4]. http://dataonline.bmkg.go.id.

Janesonia KI. 2019. Study of design principles from aspects of thermal comfort in tropical humid climates. Case study: the city of Surabaya is in the type of highrise building, midrise building, and lowrise building [dissertation]. [Bandung]: Institut Teknologi Bandung.

Jessica S. 2017. Physical elements in buildings and flats environment in maintaining flats: case study of Rusunawa Pesakih and Rusunawa Tambora [dissertation]. [Bandung]: Universitas Parahyangan.

Kusumastuty KD, Poerbo HW, Koerniawan MD. 2018. Climate-sensitive urban design through Envi-Met simulation: case study in Kemayoran, Jakarta. IOP Conf Ser: Earth Environ Sci. 129(1). doi:10.1088/1755-1315/ 129/1/012036.

Olgyay V. 1962. Design with climate: bioclimatic approach to architectural regionalism-new and expanded edition. Princeton: Princeton University Press.

Pitaloka PDP, Agus S, Jimmy S. 2018. Penerapan aspek efisiensi terhadap sirkulasi rumah susun Pasar Rumput [Application of efficiency aspects to the circulation of Pasar Rumput flats]. Prosiding seminar nasional cendekiawan buku 1: teknik, kedokteran hewan, kesehatan, lingkungan, dan lanskap [Proceedings of the national seminar for scholars of book 1: engineering, veterinary medicine, health, environment, and landscapes]. p. 583-589. doi:10.25105/SEMNAS.VOI0.3477.

Prayitno B. 2013. An analysis on spatial permeability and fluid dynamics of wind and thermal in tropical riverside residential areas of Banjarmasin City, Indonesia [Analisis permibilitas keruangan dan dinamika fluida angin dan suhu kawasan permukiman tropis sungai di Kota. Jurnal Manusia dan Lingkungan. 20(2):199-212.

Putri TA. 2018. Studi permukiman penduduk di Kecamatan Tanjung Karang Pusat, Kota Bandar Lampung [Study of population settlements in Tanjung Karang Pusat District, Bandar Lampung City]. Jurnal Penelitian Geografi. 6(3).

Sugangga M, Janesonia KI, Illiyin DF, Koerniawan MD. 2018. Thermal Comfort Assessment in the Open Space in Bandung Case Study Dago Street and Riau Street. IOP Conf Ser: Earth Environ Sci. 152(1). doi:10.1088/1755-1315/ 152/1/012010.

Taleghani M, Kleerekoper L, Tenpierik M, Van Den Dobbelsteen A. 2015. Outdoor thermal comfort within five different urban forms in the Netherlands. Build Environ. 83:65-78. doi:10.1016/j.buildenv.2014.03.014.

Wiarni S, Mononimbar W, Supardjo S. 2018. Analisis tingkat kekumuhan kawasan permukiman di Kecamatan Kotamobagu Timur [Analysis of the level of slums in residential areas in East Kotamobagu District]. Spasial. 5(1):6170 . 